\title{
EVALUASI PENIALAIAN KINERJA GURU BERSERTIFIKASI DI SD INPRES 25 KABUPATEN SORONG TAHUN 2017
}

\author{
ETTI HERAWATI \\ SD Inpres 25 Kabupaten Sorong
}

\begin{abstract}
ABSTRAK
Penelitian ini bertujuan untuk mengevaluasi Penialaian Kinerja Guru Bersertifikasi di SD Inpres 25 Kabupaten Sorong. di Kabupaten Sorong, ditinjau dari empat kompetensi, yaitu: kompetensi kepribadian, kompetensi pedagogik, kompetensi sosial, dan kompetensi profesional.. Penelitian ini merupakan penelitian evaluasi dengan model Goal Oriented of Evaluation. Subjek penelitian adalah 78 orang Guru Bersertifikasi di SD Inpres 25 Kabupaten Sorong. Data dikumpulkan dengan metode wawancara, lembar observasi, lembar penilaian, dan dokumentasi. Validasi instrumen dilakukan dengan validasi isi dan validasi konstruk. Data hasil penelitian dianalisis menggunakan statistik deskriptif. Hasil analisis deskriptif kuantitatif menunjukkan bahwa rata-rata nilai PK Guru secara keseluruhan guru Bersertifikasi di SD Inpres 25 Kabupaten Sorong mempunyai kinerja dengan kategori baik. Namun dilihat dari masing-masing kompetensi, tiga kompetensi mendapatkan penilaian cukup, yaitu kompetensi pedagogik, kompetensi sosial dan kompetensi profesional, sedangkan kompetensi kepribadian mendapatkan penilaian baik.
\end{abstract}

Kata kunci : Kinerja, Guru, bersertifikasi.

\begin{abstract}
This study aims to evaluate the Performance Assessment of Certified Teachers at SD Inpres 25, Sorong Regency. in Sorong Regency, in terms of four competencies, namely: personality competence, pedagogical competence, social competence, and professional competence. This research is an evaluation research with the Goal Oriented of Evaluation model. The research subjects were 78 Certified Teachers at SD Inpres 25, Sorong Regency. Data were collected by interview method, observation sheet, assessment sheet, and documentation. Instrument validation is done by content validation and construct validation. Research data were analyzed using descriptive statistics. The results of the quantitative descriptive analysis showed that the average value of Teacher PK overall of Certified teachers in SD Inpres 25 of Sorong Regency had good performance. But judging from each competency, three competencies get an adequate rating, namely pedagogical competence, social competence and professional competence, while personality competencies get a good rating.
\end{abstract}

Keywords: Performance, Teacher, certified.

\section{PENDAHULUAN}

Upaya untuk meningkatkan mutu pendidikan di Indonesia telah lama dilakukan. Peningkatan mutu merupakan salah satu prioritas pembangunan di bidang pendidikan. Berbagai inovasi dan program pendidikan juga telah dilaksanakan, antara lain penyempurnaan kurikulum, pengadaan buku ajar, peningkatan mutu guru dan tenaga kependidikan, dengan melalui berbagai pelatihan dan peningkatan kualifikasi pendidikan, peningkatan manajemen pendidikan serta pengadaan fasilitas pendukung termasuk laboratorium dan fasilitas lainnya. Walaupun mutu pendidikan secara umum masih belum meningkat secara signifikan. Saat ini kurikulum yang diberlakukan di Indonesia merancang agar anak lebih aktif, kreatif, inovatif serta mampu mengikuti pembelajaran dengan semangat yang baik. Selain menciptakan sekolah yang kondusif di dalam diri siswa sendiri juga harus memiliki bekal motivasi dan minat yang kuat untuk mengikuti dan bisa menguasai pelajaran dengan baik serta berbudi pekerti yang luhur.

Salah satu komponen pendidikan yang perlu dijadikan sebagai objek evaluasi adalah guru, karena keberadaan seorang guru memegang peranan sangat esensial dan strategis dalam penyelenggaraan pendidikan serta langsung bersentuhan dengan siswa.
Keefektifan pelaksanaan peran guru sebagai agen pembelajaran tergantung pada tingkat kompetensi guru yang bersangkutan, yang mencakup kemampuan akademik, sosial, kepribadian dan kemampuan lainnya.

Guru merupakan bidang pekerjaan profesional sejajar dengan profesi lain mengandung makna bahwa tidak semua orang dapat dikatakan sebagai guru. Dalam pengertian formal guru hanya dapat disandang oleh seseorang yang sudah menamatkan pendidikan profesi guru. Pendidikan profesi merupakan syarat mutlak bagi guru baik jenjang pendidikan dasar maupun jenjang pendidikan menengah.

Dalam menjalankan tugas utama, guru dituntut memiliki kompetensi sebagai kemampuan untuk menjalankan tugasnya. Kompetensi guru digolongkan atas empat kompetensi yaitu: kompetensi pedagogik, kompetensi profesional, kompetensi kepribadian, dan kompetensi sosial. Keempat kompetensi tersebut merupakan satu kesatuan yang utuh dan dapat diperoleh melalui pendidikan profesi guru. Guru profesional wajib memiliki keempat profesi di atas, sebagai persyaratan profesi maka menjadi sangat penting atas penguasaan kompetensi bagi guru.

Kompetensi pedagogik terkait antara lain dengan kemampuan guru memahami dan mengaplikasi ilmu- 
ilmu pendidikan pada peserta didik. Kompetensi pofesional menyangkut penguasaan mata pelajaran yang diampu secara luas dan mendalam termasuk mata ilmu pendukungnya. Kompetensi kepribadian terkait dengan sosok pribadi guru yang mengacu pada individu merupakan panutan bagi siswa maupun masyarakat, segala sikap maupun perbuatan guru mencerminkan pribadi yang utuh terutama dari aspek moral tidak melakukan perbuatan yang bertentangan dengan profesi guru. Kompetensi sosial berkaitannya dengan kemampuan untuk bermasyarakat karena kehidupan guru tidak terlepas dari masyarakat pada umumnya.

Pelaksanaan sertifikasi guru dimulai pada Tahun 2007 setelah diterbitkannya Peraturan Mendiknas Nomor 18 Tahun 2007 tentang Sertifikasi bagi Guru dalam Jabatan. Namun kuota bagi guru peserta sertifikasi ditetapkan oleh pemerintah pusat melalui Departemen Pendidikan Nasional sejak tahun 2006 sehingga pelaksanaan sertifikasi Tahun 2007 dilakukan secara bersamaan dengan kuota 2006. Jumlah sasaran peserta sertifikasi guru setiap tahunnya ditentukan oleh Pemerintah dalam hal ini Departemen Pendidikan Nasional. Tahapan pelaksanaan sertifikasi guru dimulai dengan pembentukan panitia pelaksanaan sertifikasi guru di tingkat provinsi dan Kabupaten/Kota, pemberian kuota kepada dinas pendidikan provinsi dan Kabupaten/Kota, dan penetapan peserta oleh dinas pendidikan provinsi dan Kabupaten/Kota.

Jumlah guru Bersertifikasi di SD Inpres 25 Kabupaten Sorong yang lulus sertifikasi 9 orang dengan rincian sertifikasi tahun 2007 adalah 1 orang tahun 20111 orang, 20126 orang,2014 1 orang dan 20151 orang. Guru yang belum mendapat kesempatan untuk sertifikasi diberi waktu setelah memenuhi persyaratan. Proses sertifikasi ini dilakukan setiap tahun. Masing-masing daerah mendapat kuota yang ditentukan pemerintah pusat.

Keberadaan guru profesional di Kabupaten Sorong sejak Tahun 2007 sampai sekarang Tahun 2017 berdasarkan wawancara terbatas dengan siswa maupun orang tua berpendapat belum ada hasil nyata dari guru yang bersertifikat profesi dalam meningkatkan kualitas pendidikan di Kabupaten Sorong, khususnya guru Bersertifikasi di SD Inpres 25 Kabupaten Sorong. Ada kesan guru yang bersertifikat dan yang belum kinerjanya tidak ada perbedaan yang signifikan. Kinerja guru profesional harus lebih bagus, lebih teratur, lebih berkualitas dari pada guru yang belum bersertifikat profesi. Menjadi teladan dan panutan bagi guru lain, membimbing siswa dengan adil, bijaksana, profesional, dan penuh tanggung jawab. Olehnya itu, peneliti melakukan penelitian untuk mengevaluasi sejauh mana Penilaian kinerja guru Bersertifikasi profesi di Kabupaten Sorong.

\section{METODE PENELITIAN}

Penelitian ini merupakan penelitian evaluasi terhadap penilaian kinerja guru Bersertifikasi di SD
Inpres 25 Kabupaten Sorong Propinsi Papua Barat sesuai dengan Standar Kompetensi guru. Fenomena yang diteliti adalah kejadian yang telah berlalu atau sedang berlangsung. Selain itu data penelitian yang dikumpulkan merupakan data yang sudah ada pada subjek penelitian (Wiersma, 1986: 211). Dalam penelitian ini pendekatan yang digunakan adalah pendekatan deskriptif kuantitatif. Pendekatan ini digunakan untuk mendiskripsikan kondisi sebenarnya dari subjek penelitian berdasarkan objek yang menjadi perhatian dalam penelitian ini.

Kriteria evaluasi ditentukan dengan pendekatan fidelity, yaitu kriteria telah ditentukan sebelum penelitian dilakukan. Kriteria tersebut adalah standar inti kompetensi guru, standar kompetensi guru mata pelajaran/kelas di SD Inpres 25 Kabupaten Sorong sesuai dengan peraturan pemerintah nomor 74 tahun 2008, yaitu tentang kompetensi pedagogik, kompetensi kepribadian, kompetensi sosial, dan kompetensi profesional guru.

Data penelitian berupa data deskriptif kuantitatif diperoleh dari hasil pemberian angket, lembar penilaian, lembar observasi dan lembar dokumentasi yang dilakukan oleh peneliti pada guru. Instrumen yang digunakan adalah instrument PK Guru yang dikeluarkan oleh Direktorat Jenderel Guru dan tenaga Kependidikan yang tertuang dalam Buku 2 Penilaian Kinerja Guru. Model evaluasi yang digunakan pada penelitian ini adalah Goal Oriented Evaluation Model.

Penelitian ini dilaksanakan di SD Inpres 25 Kabupaten Sorong Propinsi Papua Barat. Penelitian dilaksanakan pada bulan Agustus sampai dengan bulan Oktober 2017.

Subjek penelitian adalah semua guru Bersertifikasi yang mengajar di SD Inpres 25 Kabupaten Sorong, yang berjumlah 8 ( delapan) orang guru. Objek penelitian adalah hasil Penilaian kinerja guru Bersertifikas di SD Inpres 25 Kabupaten Sorong pada tahun 2017.

Varibel yang diukur pada penelitian ini adalah penilaian kinerja guru. Untuk menghindari perbedaan persepsi terhadap variabel tersebut maka diuraikan definisi operasionalnya. Definisi operasional dari penilaian kinerja guru adalah skor yang diperoleh oleh guru berdasarkan hasil penilaian kinerja guru oleh Guru senior, Kepala Sekolah, dan Pengawas Sekolah meliputi empat kompetensi guru yaitu kompetensi kepribadian, pedagogik, profesional, dan kompetensi sosial.

Penelitian ini mengukur kinerja guru yang meliputi empat kompetensi, yaitu kompetensi pedagogik, kompetensi kepribadian, kompetensi sosial, dan kompetensi profesional.

Beberapa tahapan PK GURU yang harus dilalui oleh penilai sebelum menetapkan nilai untuk setiap kompetensi, adalah sebagai berikut.

Pertemuan awal antara penilai dengan guru yang dinilai sebelum dilakukan pengamatan dilaksanakan di ruang khusus tanpa ada orang ketiga. Pada pertemuan 
ini, penilai mengumpulkan dokumen pendukung dan melakukan diskusi tentang berbagai hal yang tidak mungkin dilakukan pada saat pengamatan. Semua hasil diskusi, wajib dicatat dalam format laporan dan evaluasi per kompetensi sebagai bukti penilaian kinerja. Untuk pelaksanaan tugas tambahan yang relevan dengan fungsi sekolah/madrasah dapat dicatat dalam lembaran lain karena tidak ada format khusus yang disediakan untuk proses pencatatan ini.

Selama pengamatan di kelas dan/atau di luar kelas, penilai wajib mencatat semua kegiatan yang dilakukan oleh guru dalam pelaksanaan proses pembelajaran atau pembimbingan, dan/atau dalam pelaksanaan tugas tambahan yang relevan dengan fungsi sekolah/madrasah. Dalam konteks ini, penilaian kinerja dilakukan dengan menggunakan instrumen yang sesuai untuk masing-masing penilaian kinerja. Untuk menilai guru yang melaksanakan proses pembelajaran atau pembimbingan, penilai menggunakan instrumen PK GURU pembelajaran atau pembimbingan. Pengamatan kegiatan pembelajaran dapat dilakukan di kelas selama proses tatap muka tanpa harus mengganggu proses pembelajaran. Pengamatan kegiatan pembimbingan dapat dilakukan selama proses pembimbingan baik yang dilakukan dalam kelas maupun di luar kelas, baik pada saat pembimbingan individu maupun kelompok. Penilai wajib mencatat semua hasil pengamatan pada format laporan dan evaluasi per kompetensi tersebut atau lembar lain sebagai bukti penilaian kinerja. Jika diperlukan, proses pengamatan dapat dilakukan lebih dari satu kali untuk memperoleh informasi yang akurat, valid dan konsisten tentang kinerja seorang guru dalam melaksanakan kegiatan pembelajaran atau pembimbingan. Dalam proses penilaian untuk tugas tambahan yang relevan dengan fungsi sekolah/madrasah, data dan informasi dapat diperoleh melalui pencatatan terhadap semua bukti yang teridentifikasi di tempat yang disediakan pada masingmasing kriteria penilaian. Bukti-bukti ini dapat diperoleh melalui pengamatan, wawancara dengan pemangku kepentingan pendidikan (guru, komite sekolah, peserta didik, DU/DI mitra). Bukti-bukti yang dimaksud dapat berupa:

a) Bukti yang teramati (tangible evidences) seperti:

- dokumen-dokumen tertulis;

- kondisi sarana/prasarana (hardware dan/atau software) dan lingkungan sekolah;

- foto, gambar, slide, video; dan

- produk-produk siswa. b) Bukti yang tak teramati (intangible evidences) seperti:

- sikap dan perilaku kepala sekolah; dan

- budaya dan iklim sekolah

Pada pertemuan setelah pengamatan pelaksanaan proses pembelajaran, pembimbingan, atau pelaksanaan tugas tambahan yang relevan dengan fungsi sekolah/madrasah, penilai dapat mengklarifikasi beberapa aspek tertentu yang masih diragukan. Penilai wajib mencatat semua hasil pertemuan pada format laporan dan evaluasi per kompetensi tersebut atau lembar lain sebagai bukti penilaian kinerja. Pertemuan dilakukan di ruang khusus dan hanya dihadiri oleh penilai dan guru yang dinilai. Untuk penilaian kinerja tugas tambahan, hasilnya dapat dicatat pada Format Penilaian Kinerja sebagai deskripsi penilaian kinerja. Instrumen yang digunakan untuk

Kompetensi 1: Mengenal karakteristik peserta didik Kompetensi 2: Menguasai teori belajar dan prinsipprinsip pembelajaran yang mendidik

Kompetensi 3: Pengembangan kurikulum

Kompetensi 4:

Kompetensi 5: Memahami dan mengembangkan potensi

Kompetensi 6: Komunikasi dengan peserta didik

Kompetensi 7: Penilaian dan evaluasi

Kompetensi 8: Bertindak sesuai dengan norma agama, hukum, sosial dan kebudayaan nasional Indonesia

Kompetensi 9: Menunjukkan pribadi yang dewasa dan teladan

Kompetensi 10: Etos kerja, tanggung jawab yang baik, dan rasa bangga menjadi guru

Kompetensi 11: Bersikap inklusif, bertindak objektif, serta tidak Diskriminatif

Kompetensi 12: Komunikasi dengan sesama guru, tenaga pendidikan, orang tua peserta didik, dan masyarakat

Kompetensi 13: Penguasaan materi struktur konsep dan pola pikir keilmuan yang mendukung mata pelajaran yang diampu

Kompetensi 14: Mengembangkan keprofesian melalui tindakan ref lektif

Tahap pemberian nilai

\section{1) Penilaian}

Pada tahap ini penilai menetapkan nilai untuk setiap kompetensi dengan skala nilai $1,2,3$, atau 4. Sebelum pemberian nilai tersebut, penilai terlebih dahulu memberikan skor 0,1 , atau 2 pada masing-masing indikator untuk setiap kompetensi. Pemberian skor ini harus didasarkan kepada catatan hasil pengamatan dan pemantauan serta bukti-bukti berupa dokumen lain yang dikumpulkan selama proses PK GURU. Pemberian nilai untuk setiap kompetensi dilakukan dengan tahapan sebagai berikut.

a) Pemberian skor 0, 1, atau 2 untuk masing-masing indikator setiap kompetensi. Pemberian skor ini dilakukan dengan cara membandingkan rangkuman catatan hasil pengamatan dan pemantauan di lembar format laporan dan evaluasi per kompetensi dengan indikator kinerja masing-masing kompetensi (lihat contoh di Tabel 8). Aturan pemberian skor untuk setiap indikator adalah:

- Skor 0 menyatakan indikator tidak dilaksanakan, atau tidak menunjukkan bukti,

- Skor 1 menyatakan indikator dilaksanakan sebagian, atau ada bukti tetapi tidak lengkap

Skor 2 menyatakan indikator dilaksanakan sepenuhnya, atau ada bukti yang lengkap. 
Tabel 8. Contoh Pemberian Nilai Kompetensi tertentu pada proses PK GURU Kelas/Mata pelajaran/Bimbingan Konseling/Konselor

Penilaian Kompetensi 1: Mengenal karakteristik peserta didik

\begin{tabular}{|c|c|c|c|}
\hline \multicolumn{4}{|l|}{ Penilaian Kompetensi 1: Mengenal karakteristik peserta didik } \\
\hline Indikator & \multicolumn{3}{|c|}{ Skor } \\
\hline 1. Guru dapat mengidentifikasi karakteristik belajar setiap peserta didik di kelasnya. & 0 & 1 & 2 \\
\hline $\begin{array}{l}\text { 2. Guru memastikan bahwa semua peserta didik mendapatkan kesempatan yang sama } \\
\text { untuk berpartisipasi aktif dalam kegiatan pembelajaran. }\end{array}$ & 0 & 1 & 2 \\
\hline $\begin{array}{l}\text { 3. Guru dapat mengatur kelas untuk memberikan kesempatan belajar yang sama pada } \\
\text { semua peserta didik dengan kelainan fisik dan kemampuan belajar yang berbeda. }\end{array}$ & 0 & 1 & 2 \\
\hline $\begin{array}{l}\text { 4. Guru mencoba mengetahui penyebab penyimpangan perilaku peserta didik untuk } \\
\text { mencegah agar perilaku tersebut tidak merugikan peserta didik lainnya. }\end{array}$ & 0 & 1 & 2 \\
\hline 5. Guru membantu mengembangkan potensi dan mengatasi kekurangan peserta didik. & 0 & 1 & 2 \\
\hline $\begin{array}{l}\text { 6. Guru memperhatikan peserta didik dengan kelemahan fisik tertentu agar dapat } \\
\text { mengikuti aktivitas pembelajaran, sehingga peserta didik tersebut tidak } \\
\text { termarginalkan (tersisihkan, diolok-olok, minder, dsb.). }\end{array}$ & 0 & 1 & 2 \\
\hline Total skor yang diperoleh & \multicolumn{3}{|c|}{$\begin{array}{l}1+2+2+0+0+ \\
2=7\end{array}$} \\
\hline Skor Maksimum Kompetensi =banyaknya indikator dikalikan dengan skor terbaik & \multicolumn{3}{|c|}{$6 \times 2=12$} \\
\hline $\begin{array}{l}\text { Persentase skor kompetensi = total skor yang diperoleh dibagi dengan Skor } \\
\text { Maksimum Kompetensi dikalikan } 100 \%\end{array}$ & \multicolumn{3}{|c|}{$\begin{array}{l}7 / 12 \times 100 \%= \\
\mathbf{5 8 . 3 3 \%}\end{array}$} \\
\hline $\begin{array}{l}\text { Konversi Nilai Kompetensi }(0 \%<\mathrm{X} \leq 25 \%=1 ; 25 \%<\mathrm{X} \leq 50 \%=2 ; 50 \%<\mathrm{X} \leq \\
75 \%=3 \text {; dan } 75 \%<\mathrm{X} \leq 100 \%=4)\end{array}$ & \multicolumn{3}{|c|}{$\begin{array}{l}\mathbf{5 8 . 3 3 \%} \text { berada } \\
\text { pada rentang } 50 \% \\
<\mathrm{X} \leq 75 \% \text {, jadi } \\
\text { kompetensi } 1 \text { ini } \\
\text { nilainya } 3\end{array}$} \\
\hline
\end{tabular}

b) Nilai setiap kompetensi tersebut kemudian direkapitulasi dalam format hasil penilaian kinerja guru (Lampiran 1C bagi PK Guru Kelas/Mata Pelajaran atau 2C bagi PK Guru Bimbingan dan Konseling/Konselor) untuk mendapatkan nilai total PK GURU. Untuk penilaian kinerja guru dengan tugas tambahan yang relevan dengan fungsi sekolah/madrasah, nilai untuk setiap kompetensi direkapitulasi ke dalam format rekapitulasi penilaian kinerja untuk mendapatkan nilai PK GURU. Nilai total ini selanjutnya dikonversikan ke dalam skala nilai sesuai Peraturan Menteri Negara Pendayagunaan Aparatur Negara dan Reformasi Birokrasi No. 16 Tahun 2009. Konversi ini dilakukan dengan menggunakan rumus sebagai berikut.

Nilai PKG $($ skala 100$)=\frac{\text { Nilai PKG }}{\text { Nilai PKG Tertinggi }} \times 100$

Keterangan:

- Nilai PKG (skala 100) maksudnya nilai PK Guru Kelas/Mata Pelajaran, Bimbingan dan Konseling/Konselor atau tugas tambahan yang relevan dengan fungsi sekolah/madrasah dalam skala 0 - 100 menurut Peraturan Menteri Negara Pendayagunaan Aparatur Negara dan Reformasi Birokrasi Nomor 16 Tahun 2009.

- Nilai PKG adalah nilai PK GURU Kelas/Mata Pelajaran, Bimbingan dan Konseling/Konselor atau pelaksanaan tugas tambahan yang relevan dengan fungsi sekolah/madrasah yang diperoleh dalam proses PK GURU sebelum diubah dalam skala 0 100 menurut Peraturan Menteri Negara
Pendayagunaan Aparatur Negara dan Reformasi Birokrasi Nomor 16 Tahun 2009.

- Nilai PKG Terbaik adalah nilai terbaik PK GURU yang dapat dicapai, yaitu $56(=14 \times 4)$ bagi PK GURU pembelajaran (14 kompetensi), dan 68 (=17 $\mathrm{x}$ 4) bagi PK Guru pembimbingan (17 kompetensi). Nilai terbaik PK GURU dengan tugas tambahan disesuaikan dengan instrumen terkait untuk masingmasing tugas tambahan yang sesuai dengan fungsi sekolah/madrasah.

c) Berdasarkan hasil konversi nilai PK GURU ke dalam skala nilai sesuai dengan PermenegPAN dan RB Nomor 16 tahun 2010 tentang Jabatan Fungsional Guru dan Angka Kreditnya, selanjutnya dapat ditetapkan sebutan dan persentase angka kreditnya sebagaimana tercantum dalam tabel 11 .

Tabel 11. Konversi Nilai Kinerja Hasil PK GURU ke persentase Angka Kredit

\begin{tabular}{|c|c|c|}
\hline $\begin{array}{c}\text { Nilai Hasil } \\
\text { PK GURU }\end{array}$ & Sebutan & $\begin{array}{c}\text { Persentase } \\
\text { Angka kredit }\end{array}$ \\
\hline $91-100$ & Amat baik & $125 \%$ \\
\hline $76-90$ & Baik & $100 \%$ \\
\hline $61-75$ & Cukup & $75 \%$ \\
\hline $51-60$ & Sedang & $50 \%$ \\
\hline$\leq 50$ & Kurang & $25 \%$ \\
\hline
\end{tabular}

d) Setelah melaksanakan penilaian, penilai wajib memberitahukan kepada guru yang dinilai tentang nilai hasil PK GURU berdasarkan bukti catatan untuk setiap kompetensi. Penilai dan guru yang dinilai melakukan refleksi terhadap hasil PK GURU, sebagai 
upaya untuk perbaikan kualitas kinerja guru pada periode berikutnya.

e) Jika guru yang dinilai dan penilai telah sepakat dengan hasil penilaian kinerja, maka keduanya menandatangani format laporan hasil penilaian kinerja guru tersebut (Lampiran 1C untuk Guru Pembelajaran atau Lampiran 2C untuk Guru Pembimbingan BK/Konselor). Format ini juga ditandatangani oleh kepala sekolah.

f) Khusus bagi guru yang mengajar di 2 (dua) sekolah atau lebih (guru multi sekolah/madrasah), maka penilaian dilakukan di sekolah/ madrasah induk. Meskipun demikian, penilai dapat melakukan pengamatan serta mengumpulkan data dan informasi dari sekolah/madrasah lain tempat guru mengajar atau membimbing.

Penelitian ini bersifat deskriptif evaluatif dengan tujuan untuk memberikan gambaran nyata tentang hasil Penilaian kinerja guru Bersertifikasi sesuai dengan standar kompetensi guru di SD Inpres 25 Kabupaten Sorong. Teknik analisis data menggunakan analisis deskriptif kuantitatif. Analisis data kuantitatif dilakukan dengan teknik diskriptif yaitu mendeskripsikan tiap-tiap data dari indikator evaluasi. Hasil analisis kemudian dibandingkan dengan kriteria penilaian yang telah ditentukan berdasarkan rata-rata ideal dan simpangan baku ideal yang dapat dicapai oleh instrumen.

Letak perbedaan antara penelitian dengan evaluasi pada umumnya adalah terletak pada penentuan kriteria. Kriteria tertentu digunakan dalam evaluasi untuk memberikan dasar pertimbangan dan harga terhadap sesuatu yang dievaluasi. Dalam Evaluasi Penialaian Kinerja Guru Bersertifikasi di SD Inpres 25 Kabupaten Sorong diperlukan kriteria tertentu yang digunakan untuk memberikan pertimbangan nilai dari kinerja guru tersebut. Dengan adanya kriteria seorang evaluator dapat memberikan pertimbangan mengenai komponen-komponen yang dianggap sudah memenuhi syarat atau sudah sesuai, memerlukan perbaikan atau bahkan dirombak total dan sebagainya.

Terdapat empat jenis kriteria evaluasi yang dikembangkan melalui model-model evaluasi yang digunakan. Kriteria tersebut adalah: pre-ordinate, fidelity, mutual adaptive, dan process. Dari keempat kriteria tersebut, pendekatan yang digunakan dalam penelitian ini adalah pendekatan fidelity, dimana kriteria ditetapkan sebelum evaluator turun ke lapangan. Pada pendekatan ini kriteria penilaian mengacu pada empat kompetensi guru. Kriteria Guru hasil penilaian kinerja guru sebagai berikut :

\begin{tabular}{|c|c|c|}
\hline $\begin{array}{c}\text { Nilai Hasil PK } \\
\text { GURU }\end{array}$ & Sebutan & $\begin{array}{c}\text { Persentase } \\
\text { Angka kredit }\end{array}$ \\
\hline $91-100$ & Amat baik & $125 \%$ \\
\hline $76-90$ & Baik & $100 \%$ \\
\hline $61-75$ & Cukup & $75 \%$ \\
\hline $51-60$ & Sedang & $50 \%$ \\
\hline$\leq 50$ & Kurang & $25 \%$ \\
\hline
\end{tabular}

3. PEMBAHASAN
Penelitian ini telah dilaksanakan di SD Inpres 25 Kabupaten Sorong. Deskripsi hasil penelitian disajikan berikut ini. Bab ini akan menguraikan tentang deskripsi hasil penelitian, dan pembahasan hasil penelitian tentang Penilaian kinerja Guru Bersertifikasi di SD Inpres 25 Kabupaten Sorong. Ada empat kompetensi kinerja guru yang akan dilihat yaitu kompetensi kepribadian, kompetensi pedagogik, kompetensi sosial, dan kompetensi profesional.

Data Penilaian kinerja guru menurut penilaian Guru Senior, Kepala Sekolah, dan Pengawas Sekolah terdiri dari penilaian kinerja guru yang mencakup perencanaan pembelajaran dan pelaksanaan pembelajaran. Keduanya meliputi kompetensi pedagogik dan kompetensi sosial kemudian kompetensi kepribadian dan kompetensi profesional. Masing-masing kompetensi akan dijabarkan sebagai berikut.

Berdasarkan data, kompetensi Pedagogik guru diperoleh kategori Amat Baik sebanyak 2 orang atau sebesar $80 \%$, Baik sebanyak 7 atau sebesar $10 \%$, dan Cukup sebanyak 2 atau sebesar $10 \%$. Perolehan skor Penilaian Kinerja Guru kompetensi pedagogik disajikan pada Tabel 16 berikut ini.

Tabel 16 Perolehan skor Kompetensi Pedagogik Guru dari Penilaian Kinerja Guru

\begin{tabular}{|c|c|c|c|}
\hline Rentang Nilai & Kategori & Jumlah & Prosentase \\
\hline $91-100$ & Amat baik & 2 & 18.18 \\
\hline $76-90$ & Baik & 7 & 63.63 \\
\hline $61-75$ & Cukup & 2 & 18.18 \\
\hline $51-60$ & Sedang & 0 & 0.00 \\
\hline$\leq 50$ & Kurang & 0 & 0.00 \\
\hline \multicolumn{2}{|c|}{ Jumlah } & 11 & 100 \\
\hline
\end{tabular}

Berdasarkan Tabel 16 di atas, tampak bahwa 18,18\% guru memiliki kompetensi pedagogik dalam kategori amat baik. $863.63 \%$ dari kinerja kompetensi pedagogik dalam kategori baik. $18.18 \%$ dari kinerja kompetensi pedagogik dalam kategori cukup. Hal ini menunjukkan bahwa secara umum, kinerja guru berdasarkan kompetensi pedagogik menurut penilaian kinerja Guru berada pada kriteria cukup.

Berdasarkan data, kompetensi Kepribadian guru diperoleh kategori Amat Baik sebanyak 2 orang atau sebesar $18.18 \%$, Baik sebanyak 7 atau sebesar 63.63\%, dan Cukup sebanyak 2 atau sebesar $18.18 \%$. Perolehan skor Penilaian Kinerja Guru kompetensi Kepribadian disajikan pada Tabel 17 berikut ini.

Tabel 17 Perolehan skor Kompetensi Kepribadian Guru dari Penilaian Kinerja Guru

\begin{tabular}{|c|c|c|c|}
\hline Rentang Nilai & Kategori & Jumlah & Prosentase \\
\hline $91-100$ & Amat baik & 2 & 18.18 \\
\hline $76-90$ & Baik & 9 & 81.81 \\
\hline $61-75$ & Cukup & 0 & 0.00 \\
\hline $51-60$ & Sedang & 0 & 0.00 \\
\hline$\leq 50$ & Kurang & 0 & 0.00 \\
\hline \multicolumn{2}{|c|}{ Jumlah } & 11 & 100 \\
\hline
\end{tabular}

Berdasarkan Tabel 17 di atas, tampak bahwa 18.18\% guru memiliki kompetensi Kepribadian dalam kategori 
g $\left\|\prod_{772406}\right\|_{823002}$

amat baik. $91.91 \%$ dari kinerja kompetensi Kepribadian dalam kategori baik.. Hal ini menunjukkan bahwa secara umum, kinerja guru berdasarkan kompetensi Kepribadian menurut penilaian kinerja Guru berada pada kriteria Baik.

Berdasarkan data, kompetensi Sosial guru diperoleh kategori Amat Baik sebanyak 1 orang atau sebesar $9.09 \%$, Baik sebanyak 3 atau sebesar $27.27 \%$, dan Cukup sebanyak 7 atau sebesar $63.63 \%$. Perolehan skor Penilaian Kinerja Guru kompetensi Sosial disajikan pada Tabel 18 berikut ini.

Tabel 18 Perolehan skor Kompetensi Sosial Guru dari Penilaian Kinerja Guru

\begin{tabular}{|c|c|c|c|}
\hline Rentang Nilai & Kategori & Jumlah & Prosentase \\
\hline $91-100$ & Amat baik & 1 & 18.18 \\
\hline $76-90$ & Baik & 3 & 27.27 \\
\hline $61-75$ & Cukup & 7 & 63.63 \\
\hline $51-60$ & Sedang & 0 & 0.00 \\
\hline$\leq 50$ & Kurang & 0 & 0.00 \\
\hline \multicolumn{2}{|c|}{ Jumlah } & 11 & 100 \\
\hline
\end{tabular}

Berdasarkan Tabel 18 di atas, tampak bahwa $18.18 \%$ guru memiliki kompetensi Sosial dalam kategori amat baik. $27.27 \%$ dari kinerja kompetensi Sosial dalam kategori baik. $63.63 \%$ dari kinerja kompetensi Sosial dalam kategori cukup. Hal ini menunjukkan bahwa secara umum, kinerja guru berdasarkan kompetensi Sosial menurut penilaian kinerja Guru berada pada kriteria cukup.

Tabel 20 Kriteria Penilaian Kompetensi Guru
Berdasarkan data, kompetensi Profesional guru diperoleh kategori Amat Baik sebanyak 1 orang atau sebesar 1,32\%, Baik sebanyak 18 atau sebesar 23,68\%, dan Cukup sebanyak 57 atau sebesar $75 \%$. Perolehan skor Penilaian Kinerja Guru kompetensi Profesional disajikan pada Tabel 19 berikut ini.

Tabel 19 Perolehan skor Kompetensi Profesional Guru dari Penilaian Kinerja Guru

\begin{tabular}{|c|c|c|c|}
\hline Rentang Nilai & Kategori & Jumlah & Prosentase \\
\hline $91-100$ & Amat baik & 1 & 18.18 \\
\hline $76-90$ & Baik & 9 & 81.81 \\
\hline $61-75$ & Cukup & 1 & 18.18 \\
\hline $51-60$ & Sedang & 0 & 0.00 \\
\hline$\leq 50$ & Kurang & 0 & 0.00 \\
\hline \multicolumn{2}{|c|}{ Jumlah } & 11 & 100 \\
\hline
\end{tabular}

Berdasarkan Tabel 19 di atas, tampak bahwa $18.18 \%$ guru memiliki kompetensi Profesional dalam kategori amat baik. $81.81 \%$ dari kinerja kompetensi Profesional dalam kategori baik. $18.18 \%$ dari kinerja kompetensi Profesional dalam kategori cukup. Hal ini menunjukkan bahwa secara umum, kinerja guru berdasarkan kompetensi Profesional menurut penilaian kinerja Guru berada pada kriteria cukup.

Dalam Evaluasi Penialaian Kinerja Guru Bersertifikasi di SD Inpres 25 Kabupaten Sorong diperlukan kriteria tertentu untuk memberikan pertimbangan nilai dari kinerja guru tersebut. Dalam menentukan nilai masing-masing kompetensi menggunakan kriteria sebagai berikut.

\begin{tabular}{|c|c|c|c|c|c|c|}
\hline \multirow{2}{*}{ Komptensi } & \multicolumn{5}{|c|}{ Kategori } & \multirow{2}{*}{ Kesimpulan } \\
\hline & Amat baik & baik & cukup & sedang & kurang & \\
\hline Paedagogik & 2 & 7 & 2 & 0 & 0 & Baik \\
\hline Kepribadian & 2 & 9 & 0 & 0 & 0 & Baik \\
\hline Sosial & 1 & 3 & 7 & 0 & 0 & Cukup \\
\hline Profesional & 1 & 9 & 1 & 0 & 0 & Baik \\
\hline & 6 & 28 & 10 & 0 & 0 & \\
\hline
\end{tabular}

Hasil dari penelitian ini menunjukkan bahwa kompetensi Guru Bersertifikasi di SD Inpres 25 Kabupaten Sorong yang meliputi empat kompetensi adalah sebagai berikut.

Tabel 21 Penilaian 4 Kompetensi

\begin{tabular}{|c|c|c|c|}
\hline Rentang Nilai & Kategori & Jumlah & Prosentase \\
\hline $91-100$ & Amat baik & 2 & 18.18 \\
\hline $76-90$ & Baik & 8 & 72.72 \\
\hline $61-75$ & Cukup & 1 & 09.09 \\
\hline $51-60$ & Sedang & 0 & 0.00 \\
\hline$\leq 50$ & Kurang & 0 & 0.00 \\
\hline \multicolumn{2}{|c|}{ Jumlah } & 11 & 100 \\
\hline
\end{tabular}

Dari hasil Tabel 21 di atas, terlihat bahwa Hasil Penilaian Kinerja Guru yang memperoleh kategori amat baik ada 2 orang atau sebesar $18.18 \%$.. Guru yang memperoleh kategori baik ada 8 orang atau sebesar 72.72\%.. Guru yang memperoleh kategori cukup ada 1 orang atau sebesar $09.09 \%$.. Berdasarkan kriteria yang telah ditetapkan, maka dapat disimpulkan secara umum hasil penilaian kinerja guru
Bersertifikasi di SD Inpres 25 Kabupaten Sorong dari empat kompetensi berada pada kriteria baik. Pembahasan mengenai empat kompetensi tersebut dalam melaksanakan tugas profesionalnya lebih lanjut diuraikan sebagai berikut.

Kompetensi pedagogik guru Bersertifikasi di SD Inpres 25 Kabupaten Sorong menurut penilaian Pengawas Sekolah diperoleh skor sebagai berikut, Kompetensi paedagogik guru tampak bahwa 2,63\% guru memiliki kompetensi pedagogik dalam kategori amat baik. 23,68\% dari kinerja kompetensi pedagogik dalam kategori baik. 73,68\% dari kinerja kompetensi pedagogik dalam kategori cukup. Hal ini menunjukkan bahwa secara umum, kinerja guru berdasarkan kompetensi pedagogik menurut penilaian kinerja Guru berada pada kriteria cukup.

Kompetensi kepribadian guru Bersertifikasi di SD Inpres 25 Kabupaten Sorong menurut penilaian Pengawas Sekolah diperoleh skor sebagai berikut, Kompetensi paedagogik guru tampak bahwa 21,05\% 


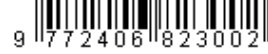

guru memiliki kompetensi Kepribadian dalam kategori amat baik. $78,95 \%$ dari kinerja kompetensi Kepribadian dalam kategori baik.. Hal ini menunjukkan bahwa secara umum, kinerja guru berdasarkan kompetensi Kepribadian menurut penilaian kinerja Guru berada pada kriteria Baik.

Pada saat ini kecenderungan tugas guru hanya mentrasfer pengetahuan tanpa memperhatikan nilainilai moral yang terkandung dalam materi tersebut, apalagi kondisi pembelajaran saat ini berorientasi pada perolehan angka-angka sebagai standarisasi kualitas pendidikan. Ada beberapa faktor yang menyebabkan kepribadian guru "kurang hidup" saat ini antara lain : 1)proses rekrutmen guru yang menekankan kemampuan teknis tanpa memperhatikan kemampuan non teknis seperti kemampuan memenajemen diri dan orang lain, malahan tidak sedikit lembaga pendidikan merekrut guru dengan tidak memperhatikan kedua keterampilan tersebut. 2) pendidikan dan pelatihan guru yang menekankan pada kemampuan guru menguasai kurikulum. 3) tidak dipahaminya profesi guru sebagai profesi panggilan hidup, artinya guru merupakan pekerjaan membantu pengembangan orang lain dan mengembangkan guru tersebut sebagai pribadi.

Kompetensi sosial guru Bersertifikasi di SD Inpres 25 Kabupaten Sorong menurut penilaian Pengawas Sekolah diperoleh skor sebagai berikut, Kompetensi sosial guru tampak bahwa 1,32\% guru memiliki kompetensi Sosial dalam kategori amat baik. 3,95\% dari kinerja kompetensi Sosial dalam kategori baik. 96,05\% dari kinerja kompetensi Sosial dalam kategori cukup. Hal ini menunjukkan bahwa secara umum, kinerja guru berdasarkan kompetensi Sosial menurut penilaian kinerja Guru berada pada kriteria cukup.

Peraturan menteri pendidikan nasional (Permendiknas) nomor 13 tahun 2007 tentang standar Pengawas Sekolah/madrasah menjelaskan bahwa Pengawas Sekolah harus memiliki dimensi kepribadian, menajerial, kewirausahaan, supervisi dan sosial. Selama ini dimensi supervisi belum dilaksanakan secara optimal oleh Pengawas Sekolah di berbagai jenjang. Pengawas Sekolah, mayoritas baru berkutat pada seputar pemenuhan kebutuhan sarana pembelajaran dan bagaimana sekolah dapat meraih nilai ujian nasional yang maksimal. Aktivitas guru belum mendapat perhatian dan sentuhan kasih sayang secara memadai.

Jalinan komunikasi antara guru dan Pengawas Sekolah memang harus dioptimalkan, kita sering keliru persepsi atau bahkan saling mencurigai karena ketidak-tahuan masing-masing pihak. Oleh karena itu sangat bijaksana apabila Pengawas Sekolah sebagai panutan warga sekolah mau mamberi contoh baik sekaligus mau membangun komunikasi dengan warga sekolah dengan penuh kekeluargaan. Selama ini Pengawas Sekolah, mayoritas baru sekadar maido (mengeluhkan) anak buahnya, sementara mereka dengan sesuka hati dan berdalih menjalankan tugas dinas luar tanpa sepengetahuan bawahannya.

Kompetensi profesional guru Bersertifikasi di SD Inpres 25 Kabupaten Sorong menurut penilaian Pengawas Sekolah diperoleh skor sebagai berikut, Kompetensi profesional guru tampak bahwa 1,32\% guru memiliki kompetensi Profesional dalam kategori amat baik. $23,68 \%$ dari kinerja kompetensi Profesional dalam kategori baik. $75 \%$ dari kinerja kompetensi Profesional dalam kategori cukup. Hal ini menunjukkan bahwa secara umum, kinerja guru berdasarkan kompetensi Profesional menurut penilaian kinerja Guru berada pada kriteria cukup.

Kompetensi profesional guru merupakan kemampuan dasar seorang guru yang memiliki keahlian khusus mengenai bidang keguruan dalam melaksanakan tugas dan kewajibannya baik sebagai pengajar maupun sebagai pendidik dengan penuh rasa tanggung jawab dan layak. Kompetensi profesional guru sangat diperlukan guna mengembangkan kualitas dan aktivitas tenaga kependidikan dalam hal ini guru. Oleh karena itu tingkat profesional guru di suatu sekolah dapat dijadikan barometer bagi mutu dan keberhasilan pendidikan di sekolah.

\section{KESIMPULAN}

Berdasarkan hasil penelitian dan pembahasan, maka dapat disimpulkan sebagai berikut :

1. Penguasaan kompetensi pedagogik guru Bersertifikasi di SD Inpres 25 Kabupaten Sorong dalam kategori cukup.

2. Penguasaan kompetensi kepribadian guru Bersertifikasi di SD Inpres 25 Kabupaten Sorong dalam kategori baik.

3. Penguasaan kompetensi sosial guru Bersertifikasi di SD Inpres 25 Kabupaten Sorong kategori cukup.

4. Penguasaan kompetensi profesional guru Bersertifikasi di SD Inpres 25 Kabupaten Sorong kategori cukup.

\section{DAFTAR PUSTAKA}

Dirjen GTK. (2017). Buku 2 Penilaian Kinerja Guru. Jakarta

Briggs, M., et. al. (2008). Assessment for Learning and Teaching in Primary Schools $\left(2^{\text {nd }} e d\right)$. Glasgow: Learning Matters Ltd.

Depdiknas. (2005). Undang-undang RI nomor 14 tahun2005 tentang Guru dan Dosen

Edih Supardi. (2005). Kinerja guru kejuruan SMKN 1 Kalasan Sleman Sorong. Penelitian Manajemen Pendidikan, tidak diterbutkan, Sorong: PPs UNY

Farida Sarimaya. (2008). Sertifikasi guru. Apa, Mengapa dan Bagaimana?Bandung: Yrama Widya

Fernandes, H. J. X. (1984). Evaluation of educational programs. Jakarta: INS/78/030 -National Education Planing - Evaluation and Curriculum Development. 
ani Sukarjo. (2005). Evaluasi Penialaian Kinerja guru SMA Negeri di Kabupaten Bantul. Penelitian Manajemen Pendidikan, tidak diterbitkan, Sorong: PPs UNY

Gomes, C. F. (1997). Manajemen sumber daya manusia. Sorong: Andi Offset

Kaufman, R., \& Thomas, S. (1980). Evaluation without fear. New York, NY: New Viewpoint

Martinis Yamin. (2006). Sertifikasi profesi keguruan di Indonesia. Jakarta: Gaung Persada Press

Marzano, R. J. (2006). Classroom assessment \& grading that work. Alexandria, Virginia USA: Association for Supervision and Curriculum Development

Masnur Muslich. (2007). Sertifikasi guru mепијu profesionalisme pendidik. Jakarta: Buki Aksara

Maton, K., \& Moore, R. (2010). Social realism, knowledge and the sociology of education: coalitions of the mind. New York: Continuum.

McDavid, J. C. \& Hawthorn, L. R. L. (2006). Program evaluation \& performance measurement. An intrduction to practice. California: Sage Publication

Muchlas Samani. (2006). Mengenal sertifikasi guru di Indonesia. Jakarta: SIC dan asosiasi peneliti pendidikan Indonesia

Muhamad Rofi \& Dakkir. (2004). Faktor-faktor yang mempengaruhi kinerja guru SMP Kabupaten Magelang. Jurnal Penelitian dan Evaluasi. 2, 127-136

Mulyasa, E. (2009). Standar kompetensi dan sertifikasi guru. Bandung: Remaja RosdakaryaNitko, A. J. \& Brookhart, S. M. (2007). Educational assesment of students. New Jersey: Pearson Education.

Oemar Hamalik. (2009). Pendidikan guru. Berdasarkan pendekatan kompetensi. Jakarta: Bumi Aksara

Office of Education and Sustainable Development. (2007). Designing evaluation for education projects. Diambil tanggal 13 Juli 2017. Dari http://wateroutreach.uwex.edu/use/documents/N OAAEvalmanualFINAL.pdf

Pecheone, R.L., \& Chung, R. R (2006). Evidence in teacher education the performance assessment for california teachers (pact). Journal of Teacher Education, Vol. 57, No. 1, January/February 2006 pp. 22-36

Peraturan Menteri Pendidikan Nasional. (2007). Peraturan menteri pendidikan nasioanal nomor
16 tahun 2007 tentang standar kualifikasi akademik dan kompetensi guru.

Peraturan Menteri Pendidikan Nasional. (2007). Peraturan menteri pendidikan nasioanal nomor 18 Tahun 2007 tentang Sertifikasi bagi Guru dalam Jabatan

Peraturan Menteri Pendidikan Nasional. (2007). Peraturan menteri pendidikan nasioanal nomor 41 Tahun 2007 tentang Standar Proses

Rossi, P. H., \& Freeman, h. E, (1985). Evaluation a system approach. California: Sage Publication.

Sandberg, J. (2000). Understanding human competence at work: an interpretative approach Academy of Management Journal 2000, Vol. 43. No. 1, 9-25.

Sardiman. (1994). Interaksi dan motivasi belajar mengajar. Jakarta: Raja grafindo

Sax, G. (1980). Principles of educational and psychological measurement and evaluation. Second Edition. California: Wadsworth Publishing Company.

Schwarz, B., Dreyfus, T., \& Hershkowitz, R. (2009). Transformation of knowledge through classroom interaction. New York: Routledge.

Stronge, J. H. (2006). Evaluating teaching. A guide to current thinking and best practice. California: Corwin Press

Stufflebeam, D. L., Madaus, G. F., \& Kellaghan, T. (2002). Evaluation models. Viewpoints on educational and human services evaluation second edition. New York, USA: Kluwer Academic Publishers.

Suharsimi Arikunto. (2009). Manajemen penelitian. Jakarta: Rineka Cipta.

Suharsimi Arikunto \& Cepi Safruddin Abdul Jabar. (2009). Evaluasi program pendidikan. Pedoman teoretis Praktis bagi mahasiswa dan praktisi pendidikan. Jakarta: Bumi Aksara

Sukardi (2008). Metodologi penelitian pendidikan. Kompetensi dan praktiknya. Jakarta: Bumi Aksara

Sukardi. (2009). Evaluasi pendidikan. Prinsip \& operasionalnya. Jakarta Timur: Bumi Aksara

Suyadi Prawirosentono. (1999). Kebijakan kinerja karyawan. Yogyakarrta: BPFE

Uzer Usman. (2006). Menjadi guru profesional. Bandung: Remaja Rosdakarya

Weiss, C. H. (1972). Evaluation research. Methods of assessing program effectiveness. Englewood Cliffs, NJ: Prentice Hall. 